\title{
Protic Ionic Liquids Assisted Synthesis and Characterization of Sulfur Nanoparticles and CdS and ZnS Nanomatrials
}

\author{
B. MEENATCHI ${ }^{1}$ and V. RENUGA ${ }^{2}$ \\ ${ }^{1}$ Department of Chemistry, Cauvery College for Women, Trichy, Tamilnadu, India \\ ${ }^{2}$ Department of Chemistry, National College, Trichy, Tamilnadu, India \\ meenachemist@gmail.com
}

Received 10 February 2015 / Accepted 4 March 2015

\begin{abstract}
A series of sulfur nanoparticles (SNPs) was synthesized by wet chemical precipitation method. In this process the initial precursor sulfur powder was heated with poly ethylene glycol-600 (PEG-600) and each of six imidazolium protic ionic liquids(PILs) such as 2-methylimidazolium lactate ([2 mim] $\left.\mathrm{CH}_{3} \mathrm{CH}(\mathrm{OH}) \mathrm{COO}^{-}\right)$, 1-ethylimidazolium lactate ([1 eim] $\left.\mathrm{CH}_{3} \mathrm{CH}(\mathrm{OH}) \mathrm{COO}^{-}\right), 1$ butylimidazolium lactate([1bim] $\mathrm{CH}_{3} \mathrm{CH}(\mathrm{OH}) \mathrm{COO}^{-}$), 2-methylimidazolium glycolate ([2 mim] $\left.\mathrm{CH}_{2}(\mathrm{OH}) \mathrm{COO}^{-}\right)$, 1-ethylimidazolium glycolate([1eim] $\left.\mathrm{CH}_{2}(\mathrm{OH}) \mathrm{COO}^{-}\right)$,1-butylimidazolium glycolate([1bim] $\left.\mathrm{CH}_{2}(\mathrm{OH}) \mathrm{COO}^{-}\right)$individually for separate process. Where the imidazolium PILs act both as solvent as well as stabilizer. The obtained SNPs are having different morphology and are characterized by UV, IR, XRD, TGA, DTA and SEM with EDAX analysis. Using one of the synthesized SNPs, ZnS and CdS semiconductor nanomaterials were prepared and characterized by XRD and SEM with EDAX analysis.
\end{abstract}

Keywords: Protic ionic liquids, Nanoparticles, Semiconductor, ZnS, CdS, Optical property

\section{Introduction}

Through a simple literature survey, it is noted that the non-metal sulfur (S) in bulk, nano and micro, finds extensive technological applications such as in the production of sulfuric acid, plastics, enamels, antimicrobial agent, insecticide, fumigant, metal glass, cements in manufacture of dyes, phosphate fertilizers, gun-powder and in the vulcanization of rubber, etc. ${ }^{1-4}$. Sulfur also has a wide range of applications in the agricultural area like acting as a fungicide against apple scab disease in the cold conditions. Sulfur is considered as a highly efficient pesticide against the diseases like mildew, blackspot which destroys agriculture and vegetables $^{5-11}$.

Sulfur nanostructures are used in the synthesis of sulphur nanocomposites which are used in lithium batteries ${ }^{8,9}$, Metal sulphur compounds like $\mathrm{ZnS}$ and CdS plays a very important role in non linear optical and electroluminescent devices ${ }^{12-17}$. The conventional synthesis of SNPs through microemulsion method, which is one of the most important 
method has certain disadvantages too, that the method is complicated, separation and purification of the particles from the microemulsion, the need of oil, huge amount of surfactant, co-surfactant etc. From the view of green chemistry and large-scale production, it is necessary to develop a simple, efficient and environment-benign route for the synthesis of SNPs with controllable size and morphology.

Ionic liquids (ILs) have received the attention as alternative solvents and stabilizers for nanomaterials synthesis, because of their general ease of synthesis, stability (nonflammable, thermally stable) and low vapor pressures. Ionic liquids are having low interfacial tension which allows them to adapt to the surrounding reaction media and their relative solubility may be tuned by varying their cations and anions ${ }^{18}$. A huge numbers of nanostructured materials are synthesized by using ionic liquids as precursors ${ }^{19-21}$. Imidazolium ionic liquids posses pre-organized structures through mainly hydrogen bonds which induce structural directionality. The unique combination of adaptability towards other molecules and phases leads to ionic liquids as potential key tools in the preparation of a new generation nanostructures.

Due to the higher advantages of ionic liquids, we use imidazolium based protic ionic liquids (PILs) for SNPs synthesis. This paper imparts the new path for the synthesis SNPs. By using these SNPs as precursor ZnS \& CdS are prepared.

\section{Experimental}

2-Methylimidazole, 1-ethylimidazole, 1-butylimidazole, lactic acid, glycolic acid, sulphur powder, sodium borohydride, PEG-600 are purchased from Sigma-Aldrich and used as received without further purification. Cadmium sulphate and zinc acetate with AR quality are also purchased.

\section{Synthesis of imidazolium protic ionic liquids}

The equimolar mixture of the precursor Bronsted acids (hydroxy carboxylic acids) and Bronsted bases (substituted imidazoles) were taken in a reacting vessel and stirred for an hour using magnetic stirrer and then it was placed in a microwave and irradiated ${ }^{22}$. The protic ionic liquids are formed according the Scheme 1.
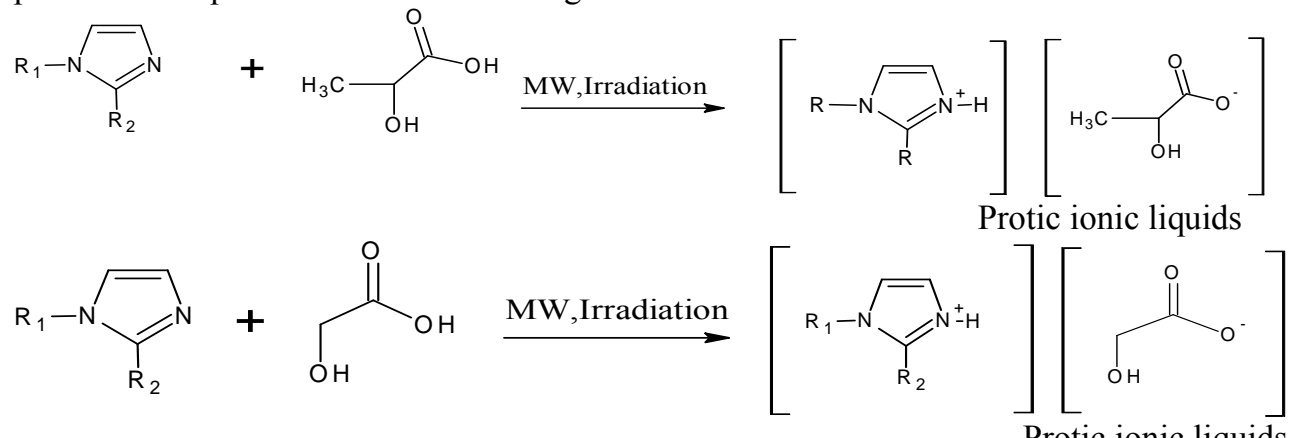

where $\mathbf{R}_{\mathbf{1}}-\mathrm{H}, \mathrm{C}_{2} \mathrm{H}_{5}$ - or $\mathrm{C}_{4} \mathrm{H}_{9}$-. $\mathbf{R}_{2}-\mathrm{H}, \mathrm{CH}_{3}$

Protic ionic liquids

Synthesis of SNPs

\section{Scheme 1}

$0.5 \mathrm{~g}$ of Sulfur powder was dispersed in $5 \mathrm{~mL}$ of PEG-600 and $3 \mathrm{~mL}$ of PILs (each of [2 mim] $\mathrm{CH}_{3} \mathrm{CH}(\mathrm{OH}) \mathrm{COO}^{-}$, [1 eim $\left.] \mathrm{CH}_{3} \mathrm{CH}(\mathrm{OH}) \mathrm{COO}^{-}\right)$, [1 bim $\left.] \mathrm{CH}_{3} \mathrm{CH}(\mathrm{OH}) \mathrm{COO}^{-}\right)$, [2 mim] $\mathrm{CH}_{2}$ $\left.(\mathrm{OH}) \mathrm{COO}^{-}\right)$, [1 eim] $\left.\mathrm{CH}_{2}(\mathrm{OH}) \mathrm{COO}^{-}\right)$, [1 bim $] \mathrm{CH}_{2}(\mathrm{OH}) \mathrm{COO}^{-}$) separately for various process). 
The yellow color mixture was stirred on a magnetic stirrer for 6 hours. Then the mixture was heated to about $120{ }^{\circ} \mathrm{C}$ for $1 \mathrm{~h}$. After cooling the mixture to room temperature, the product was washed with water and ethanol and then filtered.

\section{Synthesis of CdS Nanomaterials}

To $10 \mathrm{~mL}$ of $0.1 \mathrm{M}$ cadmium sulphate solution $0.1 \mathrm{~g}$ of SNP (obtained from [1bim] $\mathrm{CH}_{2}$ $\left.(\mathrm{OH}) \mathrm{COO}^{-}\right)$) and $3 \mathrm{~mL}$ of [1 $\left.\left.1 \mathrm{bim}\right] \mathrm{CH}_{2}(\mathrm{OH}) \mathrm{COO}^{-}\right)$were added. The mixture was stirred on a magnetic stirrer for 6 hours at $80{ }^{\circ} \mathrm{C}$. The obtained $\mathrm{CdS}$ precipitate was filtered and dried.

\section{Synthesis of ZnS Nanomaterials}

To $10 \mathrm{~mL}$ of $0.1 \mathrm{M}$ zinc acetate solution $0.1 \mathrm{~g}$ of SNP (obtained from[1 bim] $\left.\mathrm{CH}_{2}(\mathrm{OH}) \mathrm{COO}^{-}\right)$) and $3 \mathrm{~mL}$ of [1bim] $\mathrm{CH}_{2}(\mathrm{OH}) \mathrm{COO}^{-}$) were added. The mixture was stirred on a magnetic stirrer for $3 \mathrm{~h}$ and heated to $60{ }^{\circ} \mathrm{C}$ for $30 \mathrm{~min}$. The obtained $\mathrm{ZnS}$ precipitate was filtered and dried.

\section{Characterization}

The absorption spectrum was recorded by using Perkin Elmer Lambda 35 Spectrometer and the energy band gap was calculated by employing the direct formula ${ }^{13} \mathrm{E}_{\mathrm{g}}{ }^{0}(\mathrm{eV})=$ $12397.8 / \lambda_{\max }(\AA)$ where $\mathrm{E}_{\mathrm{g}}{ }^{0}$ is an energy band gap and $\lambda_{\max }$ is the wavelength at which maximum absorption is shown. The FT-IR spectra were recorded using the Jasco (FTIR 460) spectrometer.XRD was performed by using XPERT - PRO diffractometer which utilized $\mathrm{Cu}-\mathrm{K} \alpha(1.5406 \AA)$.SEM images were obtained from VEGA3-TESCAN instrument. The TGA and DTA measurements were carried out by using Perkin Elemer/TGA4000 analyzer.

\section{Results and Discussion}

All of the synthesized PILs act both as solvent and stabilizer (because of their relative solubility). The PILs itself can perform as an electronic as well as a steric stabilizer and thus can lower particle growth. The imidazolium cation of the PILs can interact with the sulfur particles more than of the anions (lactate and glycolate). Thus the imidazolium cations strongly coordinate with the sulfur thereby forming layer around SNPs. Hence they can prevent the close contact of the SNPs. Thus the synthesized SNPs are small in size.

The size of the SNP synthesized from [1bim] $\mathrm{CH}_{2}(\mathrm{OH}) \mathrm{COO}-$ ) (from Table 1) is small compared to other SNPs. which can be explained by the fact that longer the alkyl chain results higher stabilization ability and hence lower will be the size of SNP. Furthermore for the weakly coordinated anion, the size of the nanoparticles increase with increasing molecular volume (or size) of the (weakly) coordinating anion. Hence PILs with glycolate having smaller size when compare to lactate anion (Table 1).

Table 1. XRD pattern of SNPs

\begin{tabular}{ccllr}
\hline S.No & Content & \multicolumn{1}{c}{$2 \theta$} & \multicolumn{1}{c}{ hkl } & size \\
\hline 1 & a & $21.20,23.552,25.120,26.19$, & $(115),(222),(026),(224),(206)$, & 30.2894 \\
& & $27.925,28.185,37.760$ & $(313),(422)$ & \\
2 & b & $\begin{array}{l}23.152,25.903,26.773,27.78 \\
\text { (222), (026),(311),(117), }\end{array}$ & 29.7894 \\
& & $4,28.693,31.445$, & $(313),(044)$ & \\
3 & c & $21.911,22.683,23.064,25.82$ & $(220),(131),(222),(026),(311)$, & \\
& & $7,26.714,28.670,28.923,31$. & $(313),(135),(044),(137)$, & 27.7570 \\
& & $408,34.159,42.754,51.190$ & $(062),(357)$ & \\
\hline
\end{tabular}




\begin{tabular}{|c|c|c|c|c|}
\hline 4 & $\mathrm{~d}$ & $\begin{array}{l}21.960,23.159,25.990,26.79, \\
27.795,28.789,37.163\end{array}$ & $\begin{array}{l}(220),(222),(026),(311),(206), \\
(313),(317)\end{array}$ & 29.9913 \\
\hline 5 & $\mathrm{e}$ & $\begin{array}{l}23.012,26.63,27.475,27.678, \\
31.252\end{array}$ & $\begin{array}{l}(222),(311),(206),(117), \\
(044)\end{array}$ & 28.1274 \\
\hline 6 & $\mathrm{f}$ & $\begin{array}{l}23.047,25.797,26.665,27.62 \\
0,36.97,51.132\end{array}$ & $\begin{array}{l}(222),(026)(224),(206), \\
(151),(357)\end{array}$ & 25.1588 \\
\hline
\end{tabular}

Where a,b,c,d,e,f are the SNPs synthesized from [2mim] $\left.\mathrm{CH}_{3} \mathrm{CH}(\mathrm{OH}) \mathrm{COO}^{-}\right)$[1eim] $\left.\mathrm{CH}_{3} \mathrm{CH}(\mathrm{OH}) \mathrm{COO}^{-}\right)$, [1bim] $\left.\mathrm{CH}_{3} \mathrm{CH}(\mathrm{OH}) \mathrm{COO}^{-}\right)$, [2mim] $\mathrm{CH}_{2}(\mathrm{OH}) \mathrm{COO}^{-}$), [1 eim] $\left.\mathrm{CH}_{2}(\mathrm{OH}) \mathrm{COO}^{-}\right)$, [1 bim] $\mathrm{CH}_{2}(\mathrm{OH}) \mathrm{COO}^{-}$) respectively

Table 2. Band gap energies of SNPs

\begin{tabular}{cccc}
\hline S.No & Content & $\lambda_{\max }(\AA)$ & Band gap $(\mathrm{eV})$ \\
\hline 1 & Precursor S & 224.9 & 5.5125 \\
2 & $\mathrm{a}$ & 223.931 & 5.5304 \\
3 & $\mathrm{~b}$ & 221.03 & 5.6091 \\
4 & $\mathrm{c}$ & 220.98 & 5.6104 \\
5 & $\mathrm{~d}$ & 223.9 & 5.5372 \\
6 & $\mathrm{e}$ & 222.08 & 5.5826 \\
7 & $\mathrm{f}$ & 219.1 & 5.6585 \\
\hline
\end{tabular}

The strong absorption bands have absorption maximum 223.93,221.63,220.98,223.89, $221.08 \& 219.1 \mathrm{~nm}$ are observed for the SNPs obtained from the [2 mim] $\mathrm{CH}_{3} \mathrm{CH}(\mathrm{OH}) \mathrm{COO}$, [1 eim $\left.] \mathrm{CH}_{3} \mathrm{CH}(\mathrm{OH}) \mathrm{COO}^{-}\right)$, [1 bim] $\left.\left.\mathrm{CH}_{3} \mathrm{CH}(\mathrm{OH}) \mathrm{COO}^{-}\right),[2 \mathrm{mim}] \mathrm{CH}_{2}(\mathrm{OH}) \mathrm{COO}^{-}\right), \quad[1 \mathrm{eim}]$ $\left.\mathrm{CH}_{2}(\mathrm{OH}) \mathrm{COO}^{-}\right)$, [1 bim] $\mathrm{CH}_{2}(\mathrm{OH}) \mathrm{COO}^{-}$) respectively. But the precursor sulfur powder has the absorption maximum of $224.9 \mathrm{~nm}$. As shown in Figure 1.

The optical properties of SNPs are determined by knowing the band gap energy of SNPs. From the absorption peaks, the optical energy band gap was calculated by using the formula $\mathrm{E}_{\mathrm{g}}{ }^{0}(\mathrm{eV})=12397.8 / \lambda_{\max }(\AA)$ and it is compiled in Table 2 . It is clear that the calculated band gap values of the SNPs are slightly blue shifted from that of the precursor sulfur. The increase in band gap compared to precursor sulfur is due to the size effect. The Formation of SNPs is also confirmed by FT-IR analysis and it is shown in Figure 2.

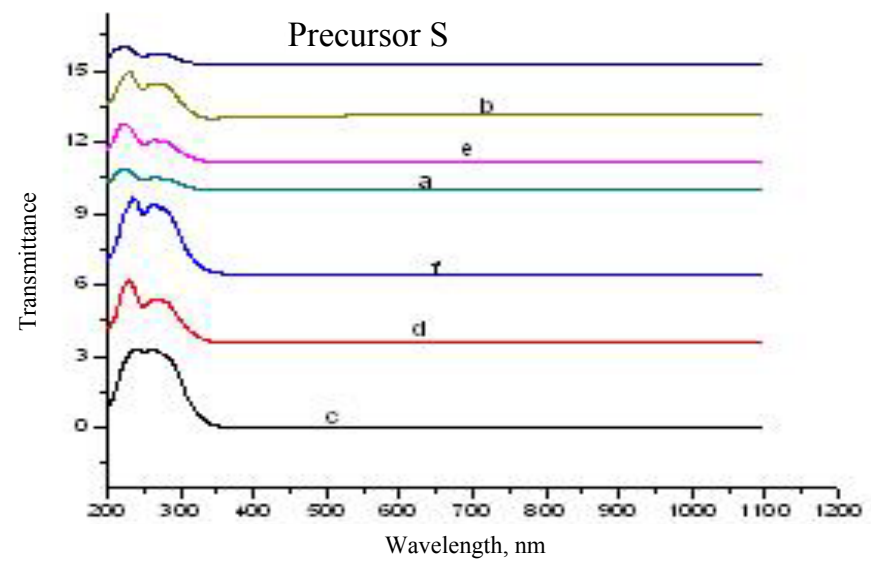

Figure 1. UV Spectrum of precursor S \& SNPs

Where a,b,c,d,e,f are the SNPs synthesized from [2 mim] $\left.\mathrm{CH}_{3} \mathrm{CH}(\mathrm{OH}) \mathrm{COO}^{-}\right)$[1 eim] $\mathrm{CH}_{3} \mathrm{CH}(\mathrm{OH})$ $\left.\left.\left.\left.\mathrm{COO}^{-}\right), \quad[1 \mathrm{bim}] \mathrm{CH}_{3} \mathrm{CH}(\mathrm{OH}) \mathrm{COO}^{-}\right),[2 \mathrm{mim}] \mathrm{CH}_{2}(\mathrm{OH}) \mathrm{COO}^{-}\right),[1 \mathrm{eim}] \quad \mathrm{CH}_{2}(\mathrm{OH}) \mathrm{COO}^{-}\right)$, [1 bim $] \mathrm{CH}_{2}$ $\left.(\mathrm{OH}) \mathrm{COO}^{-}\right)$respectively. 

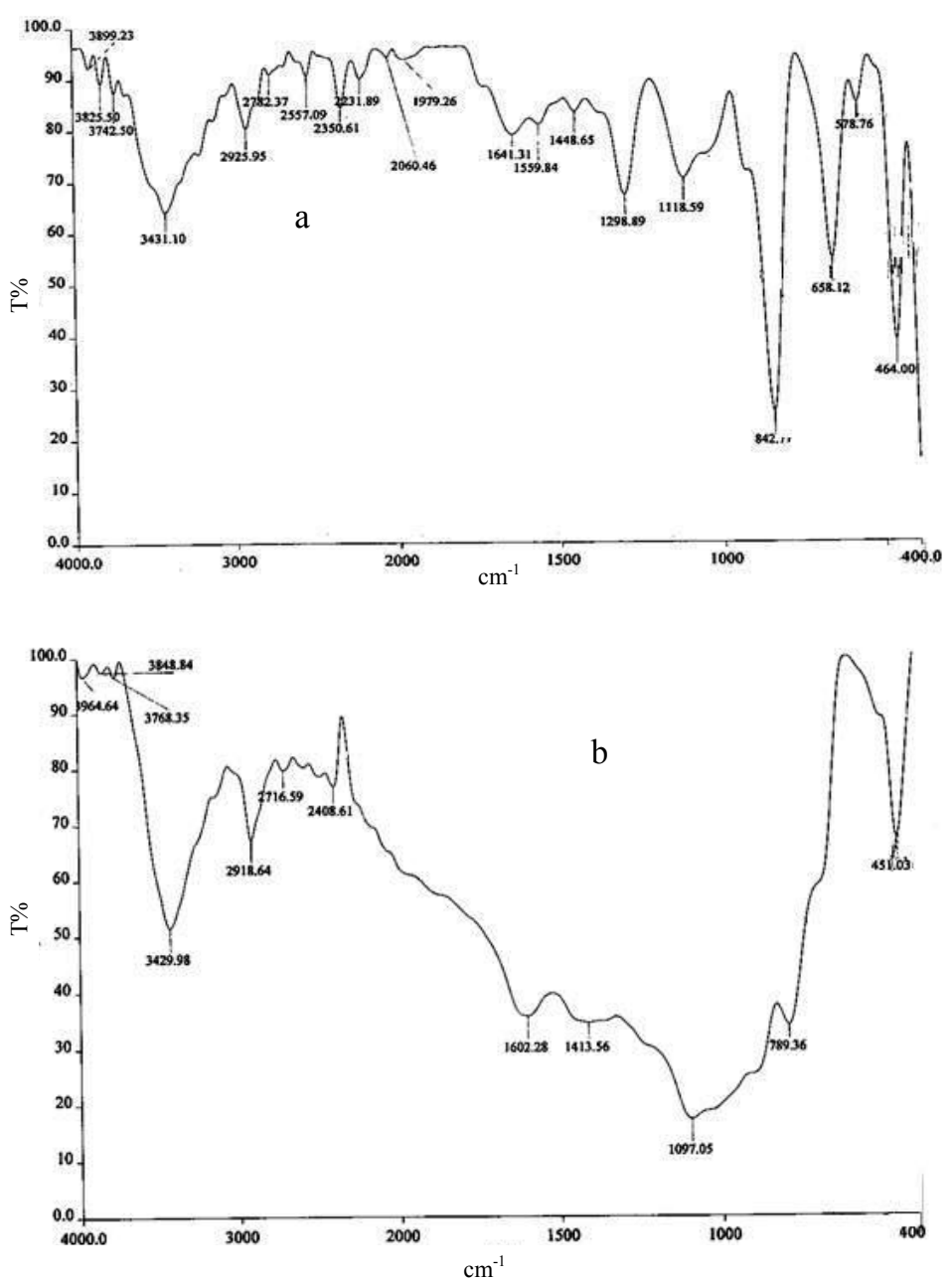

Figure 2. FT-IR Spectrum of precursor S (a) \& SNPs (b)

The XRD pattern of the synthesized SNPs, as shown in Figure 3 matches well with the standard sulfur JCPDS CAS No77-0145 confirming the formation of SNPs. The SNPs having orthorhombic structure and their lattice constants $(\mathrm{a}=10.58, \mathrm{~b}=12.923, \mathrm{c}=24.21)$ are well in agreement with the literature value $(a=10.43, b=12.84, c=24.369)$. The average sizes of SNPs using different PILs are calculated using the Debye-Scherer equation and compiled in Table 1. The SNPs synthesized from [1 bim] $\left.\left.\mathrm{CH}_{3} \mathrm{CH}(\mathrm{OH}) \mathrm{COO}^{-}\right),[1 \mathrm{bim}] \mathrm{CH}_{2}(\mathrm{OH}) \mathrm{COO}^{-}\right)$ has a size of $27.7570 \mathrm{~nm} \& 25.1588 \mathrm{~nm}$ (Table 2) respectively which is comparatively smaller in size than other SNPs obtained from rest of the PILs. The smaller size nanoparticles are obtained in the more pre-organized ionic liquids.

The SEM analysis of SNPs reveals that due to the use of various PILs all the synthesized SNPs has different shapes (Figure 4). Thus the morphology of the SNPs is tuned by the PILs. The EDAX analysis confirms that the SNPs posses purely sulfur with contains no other elemental impurities (Figure 5). 


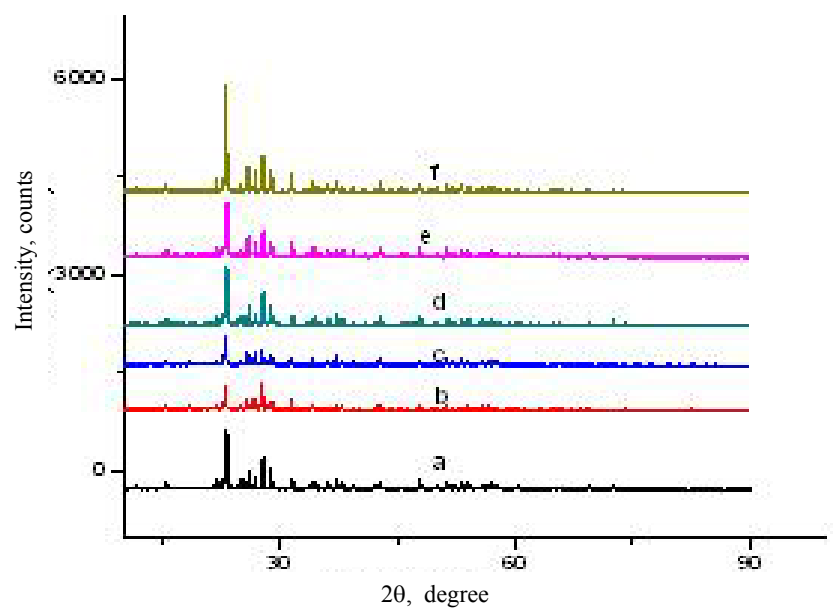

Figure 3. XRD of synthesized SNPs

The thermal analysis (TGA) of SNPs shows that all are stable up to $350{ }^{\circ} \mathrm{C}$.Particularly, the SNP synthesized from [ $1 \mathrm{bim}] \mathrm{CH}_{2}(\mathrm{OH}) \mathrm{COO}^{-}$) is thermally stable up to $420{ }^{\circ} \mathrm{C}$ because it is obtained from most thermally stable PIL due to their increased inter ionic interactions between [1bim] cation and $\mathrm{CH}_{2}(\mathrm{OH}) \mathrm{COO}^{-}$anion while the initial selenium precursor starts to decompose at $300{ }^{\circ} \mathrm{C}$ (Figure 6). Thus the SNPs posses high thermal stability. From the DTA measurement it is found that the melting point of SNPs lies between $110-115^{\circ} \mathrm{C}$ (Figure 7).

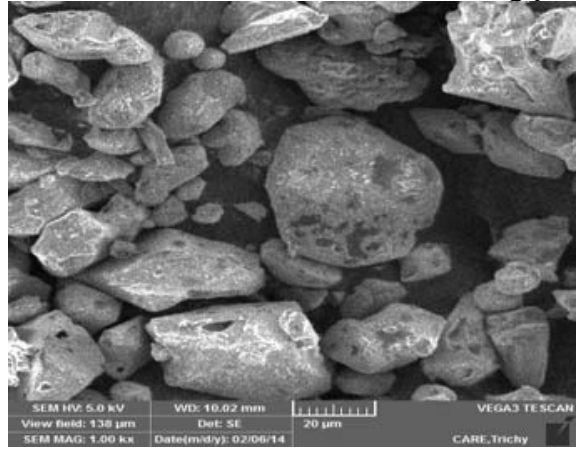

a

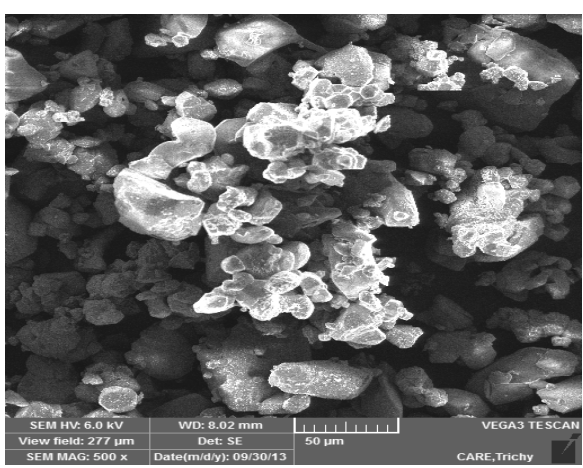

c

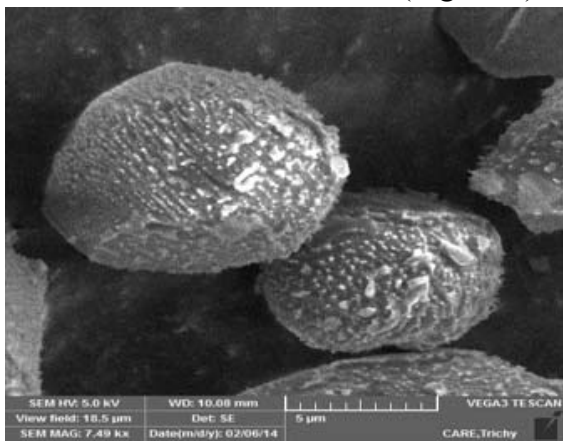

b

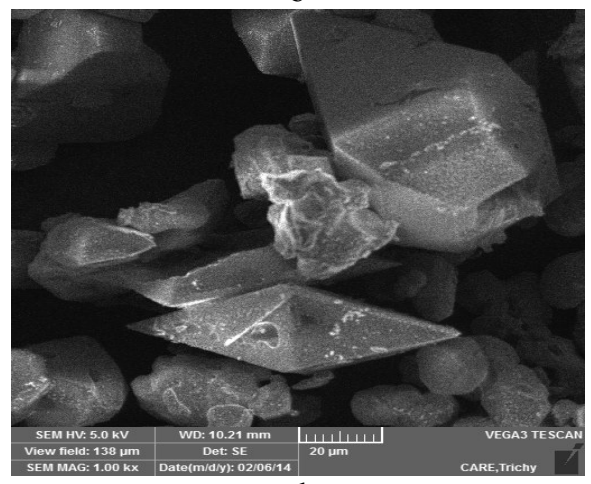

d 


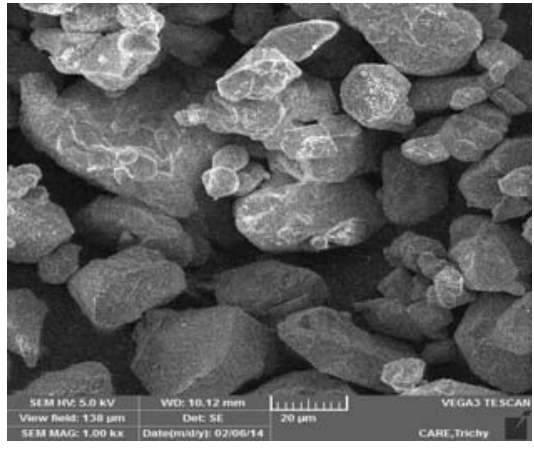

e

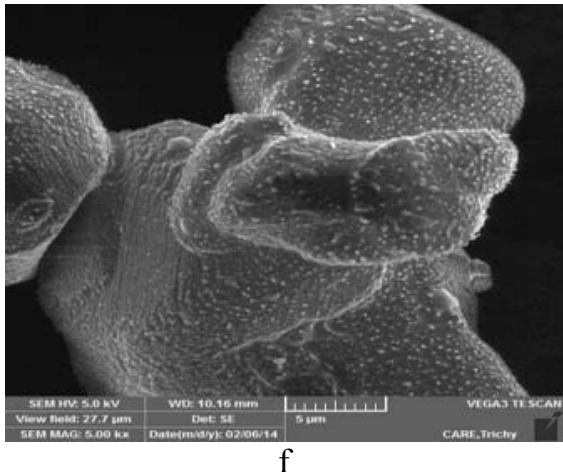

f

Figure 4. SEM images of SNPs

Where a,b,c,d,e,f are the SNPs synthesized from $[2 \mathrm{mim}] \mathrm{CH}_{3} \mathrm{CH}(\mathrm{OH}) \mathrm{COO}^{-}$) [1 eim] $\left.\left.\left.\left.\mathrm{CH}_{3} \mathrm{CH}(\mathrm{OH}) \mathrm{COO}^{-}\right), \quad[1 \mathrm{bim}] \mathrm{CH}_{3} \mathrm{CH}(\mathrm{OH}) \mathrm{COO}^{-}\right),[2 \mathrm{mim}] \mathrm{CH}_{2}(\mathrm{OH}) \mathrm{COO}^{-}\right),[1 \mathrm{eim}] \quad \mathrm{CH}_{2}(\mathrm{OH}) \mathrm{COO}^{-}\right)$, [1 bim] $\mathrm{CH}_{2}(\mathrm{OH}) \mathrm{COO}^{-}$) respectively
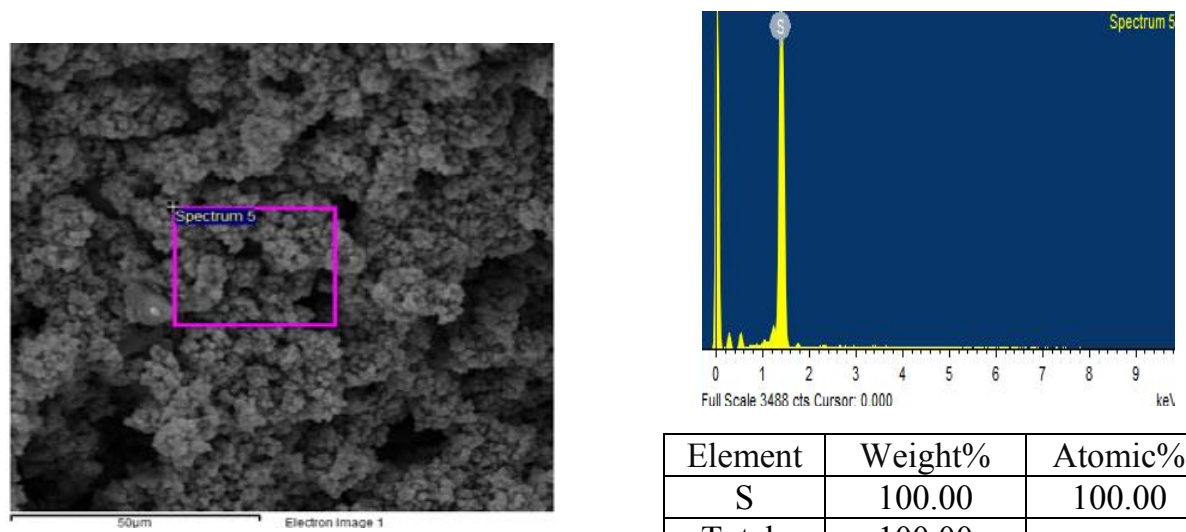

\begin{tabular}{|c|c|c|}
\hline Element & Weight $\%$ & Atomic $\%$ \\
\hline $\mathrm{S}$ & 100.00 & 100.00 \\
\hline Totals & 100.00 & \\
\hline
\end{tabular}

Figure 5. EDAX analysis of SNPs

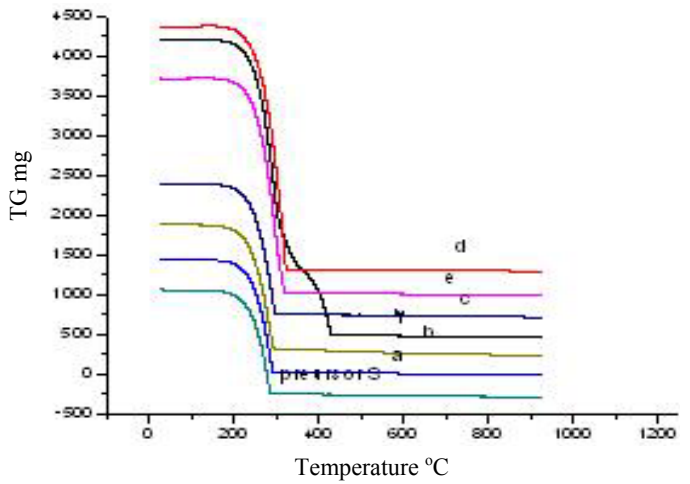

Figure 6. TGA analysis of SNPS

Where a,b,c,d,e,f are the SNPS synthesized from [2 mim] $\left.\mathrm{CH}_{3} \mathrm{CH}(\mathrm{OH}) \mathrm{COO}^{-}\right)$[1 eim] $\left.\mathrm{CH}_{3} \mathrm{CH}(\mathrm{OH}) \mathrm{COO}^{-}\right)$, [1 bim $\left.\left.\left.\left.] \mathrm{CH}_{3} \mathrm{CH}(\mathrm{OH}) \mathrm{COO}^{-}\right),[2 \mathrm{mim}] \mathrm{CH}_{2}(\mathrm{OH}) \mathrm{COO}^{-}\right),[1 \mathrm{eim}] \mathrm{CH}_{2}(\mathrm{OH}) \mathrm{COO}^{-}\right),[1 \mathrm{bim}] \mathrm{CH}_{2}(\mathrm{OH}) \mathrm{COO}^{-}\right)$ respectively 


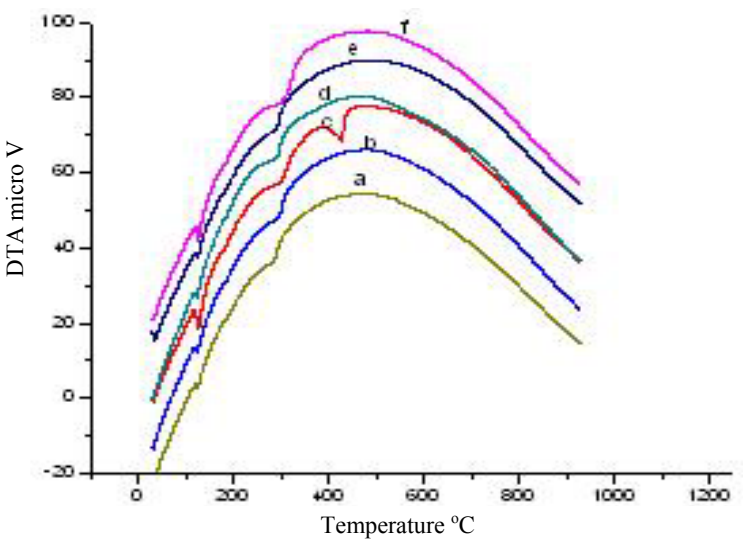

Figure 7. DTA analysis of SNPs

Where a,b,c,d,e,f are the SNPS synthesized from [2 mim] $\left.\mathrm{CH}_{3} \mathrm{CH}(\mathrm{OH}) \mathrm{COO}^{-}\right)[1$ eim $\left.] \mathrm{CH}_{3} \mathrm{CH}(\mathrm{OH}) \mathrm{COO}^{-}\right)$, [1 bim $\left.\left.\left.\left.] \mathrm{CH}_{3} \mathrm{CH}(\mathrm{OH}) \mathrm{COO}^{-}\right),[2 \mathrm{mim}] \mathrm{CH}_{2}(\mathrm{OH}) \mathrm{COO}^{-}\right),[1 \mathrm{eim}] \mathrm{CH}_{2}(\mathrm{OH}) \mathrm{COO}^{-}\right),[1 \mathrm{bim}] \mathrm{CH}_{2}(\mathrm{OH}) \mathrm{COO}^{-}\right)$ respectively.

The XRD pattern of the synthesized $\mathrm{ZnS} \& \mathrm{CdS}$ is shown in Figure 8. The XRD measurement of CdS reveals that the position of the diffracted peak matches well with the standard powder diffraction data. The several peaks of CdS 24.534, 26.41, 28.616, 36.23, $47.811,51.223,66.565$ have been obtained due to diffraction from(100), (002), (101), (102), (103), (112), (203) planes of hexagonal CdS which are in very good agreement with hexagonal structure JCPDS CAS No.77-2306. From the different $\theta$ values, the calculated average particle size is about $35.58 \mathrm{~nm}$.

Furthermore from the XRD measurements of $\mathrm{ZnS}$ (Figure 9) it is found that the position of the diffracted peak matches well with the standard powder diffraction data. The several peaks of $\mathrm{ZnS} 26.675,27.575,28.57,31.01,34.76,45.62,51.07,55.88$ have been obtained due to diffraction from (100), (101), (004), (102), (103), (105), (106), (200) planes of hexagonal $\mathrm{ZnS}$, which are in very good agreement with hexagonal wurtzite structure JCPDS CAS No.89-7385. From the different $\theta$ values, the calculated average particle size is about $27.95 \mathrm{~nm}$.

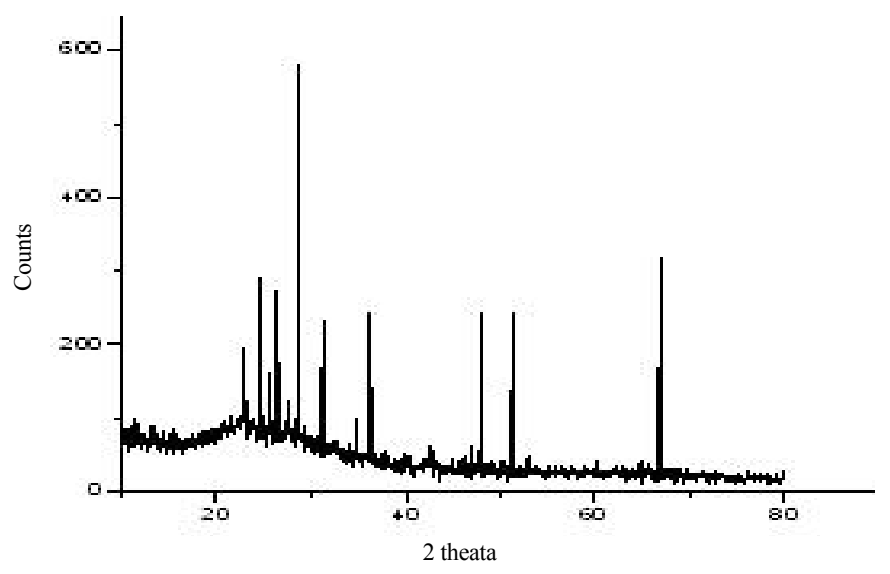

Figure 8. XRD pattern of $\mathrm{CdS}$ 


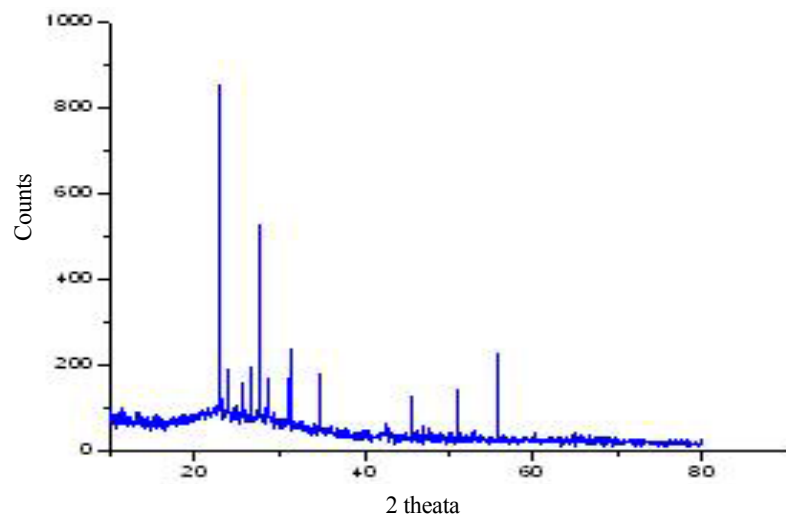

Figure 9. XRD pattern of $\mathrm{ZnS}$

The morphology of CdS found to be speckled in appearance and $\mathrm{ZnS}$ is found to be like gravel in shape using SEM analysis and it is given in Figure $10 \& 11$. The EDAX analysis of $\mathrm{CdS} \& \mathrm{ZnS}$ shows that they contain chemical composition of $\mathrm{Cd} \& \mathrm{~S}$ and $\mathrm{Zn} \& \mathrm{~S}$ respectively and not any other impurities. It is shown in Figure $12 \& 13$.

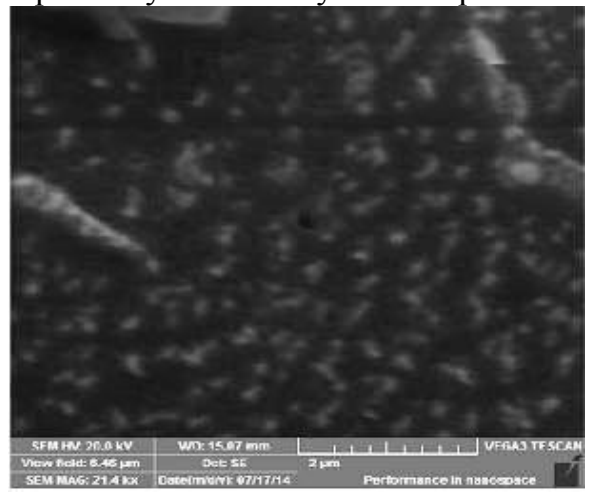

Figure 10. SEM image of CdS

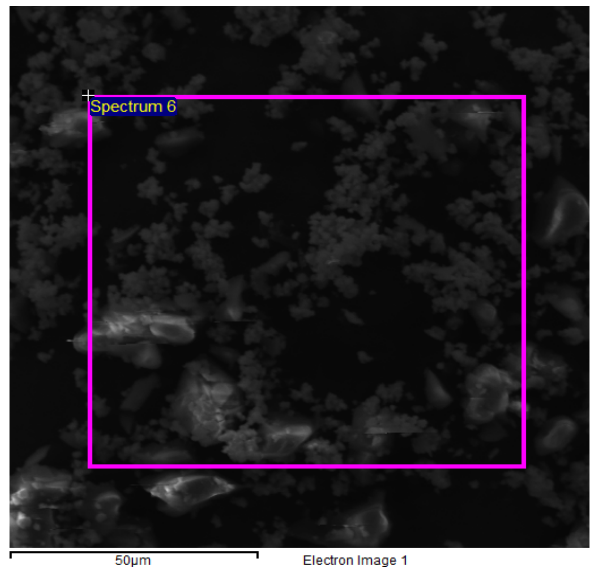

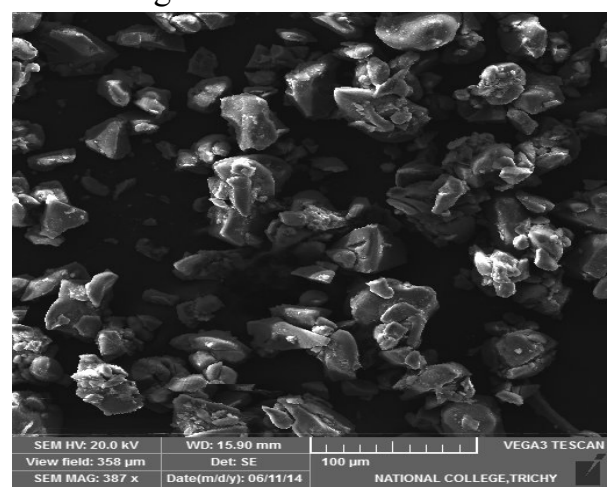

Figure 11. SEM image of $\mathrm{ZnS}$

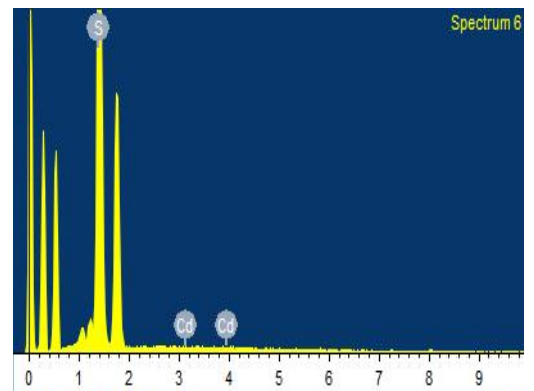

Full Scale 3488 cts Cursor: 0.000

\begin{tabular}{|c|c|c|}
\hline Full Scale 3488 cts cursor: 0.000 \\
\hline Element & Weight $\%$ & Atomic $\%$ \\
\hline Se L & 99.45 & 99.68 \\
\hline Cd L & 0.45 & 0.32 \\
\hline Totals & 100.00 & \\
\hline
\end{tabular}

Figure 12. EDAX analysis of $\mathrm{CdS}$ 

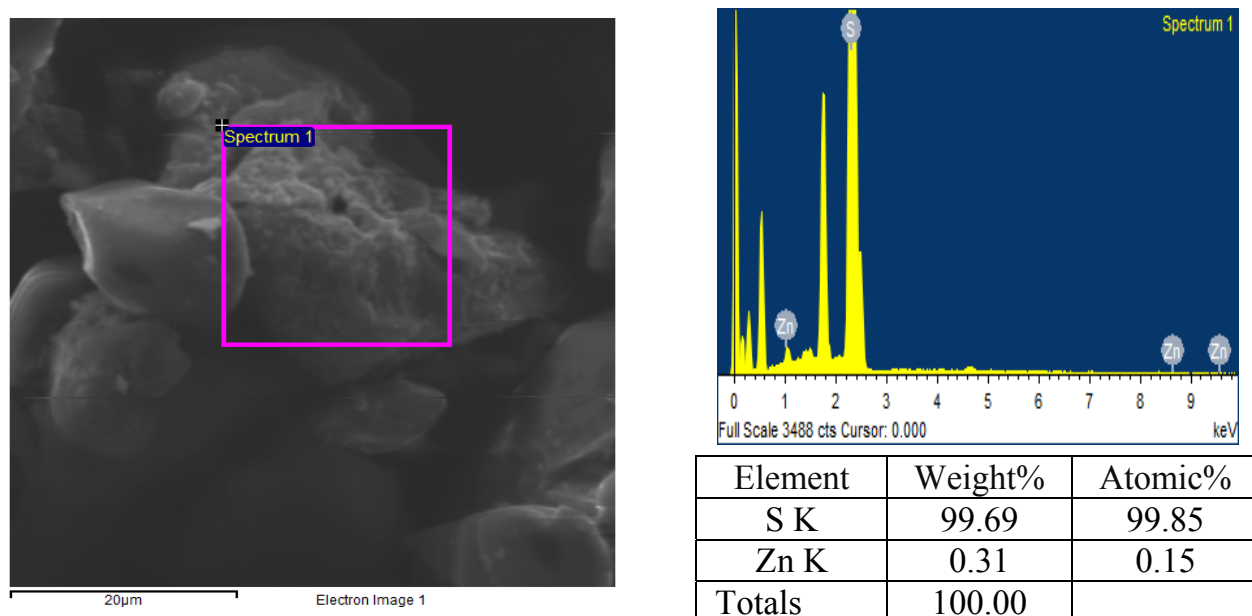

\begin{tabular}{|c|c|c|}
\hline Element & Weight $\%$ & Atomic $\%$ \\
\hline $\mathrm{S} \mathrm{K}$ & 99.69 & 99.85 \\
\hline Zn K & 0.31 & 0.15 \\
\hline Totals & 100.00 & \multicolumn{1}{|l}{} \\
\hline
\end{tabular}

Figure 13. EDAX analysis of $\mathrm{ZnS}$

\section{Conclusion}

The SNPs have been successfully synthesized using six different imidazolium protic ionic liquids as solvent as well as stabilizer. The XRD measurements confirm that the size of synthesized SNPs is found to be in the range of $25-30 \mathrm{~nm}$. The spherical morphology of the SNPs has been identified by SEM analysis. The EDAX analysis of SNPs confirms the presence of elemental sulfur and do not contain any other impurities. Furthermore the synthesized SNPs have an increased optical energy band gap and are blue shifted from the initial sulfur precursor. Thus the SNPs have a scope of optical applications. The thermal stability of the SNPs is confirmed by TGA measurements. Particularly, the SNP obtained from [1 bim] $\mathrm{CH}_{2}(\mathrm{OH}) \mathrm{COO}^{-}$) having high thermal stability.

The chalcogenide nanomaterials such as CdS \& $\mathrm{ZnS}$ are synthesized by using the SNP which is obtained from [1bim] $\left.\mathrm{CH}_{2}(\mathrm{OH}) \mathrm{COO}^{-}\right)$as a precursor. The synthesized CdS \& $\mathrm{ZnS}$ have the size $35.5834 \mathrm{~nm} \& 27.9565 \mathrm{~nm}$ respectively. The morphology and the elemental composition of CdS \& ZnS confirmed by SEM \& EDAX analysis respectively. Thus the synthesized SNPs may serve as a template to generate important nanomaterials.

\section{References}

1. Leslie K S, Millington G W M and Levell N J, J Cosmet Dermatol., 2004, 3(2), 94-98; DOI:10.1111/j.1473-2130.2004.00055.x

2. Merck Index, $13^{\text {th }}$ Edn., (Merck \& Co. Inc., USA, 2001), p. 1599

3. Lide D R, CRC Handbook of Chemistry and Physics, $85^{\text {th }}$ Edn., (CRC Press, New York, 2004), p. 30.

4. Weld J T and Gunther A, J Exp Med., 1946, 85(5), 531-542; DOI:10.1084/jem.85.5.531

5. Chaudhuri R.G and Paria S, J Colloid Sci., 2010, 343(2), 439-446; DOI:10.1016/j.jcis.2009.12.004

6. Deshpande A S, Khomane R B, Vaidya B K, Joshi R M, Harle A S and Kulkarni B D, Nanoscale Res Lett., 2008, 3, 221.

7. Xie X Y, Zheng W J, Bai Y and Liu J, Mater Lett., 2009, 63(16), 1374-1376; DOI:10.1016/j.matlet.2008.12.049 
8. Chaudhuri R G and Paria S, J Colloid Interf Sci., 2010, 343, 439-446; DOI: 10.1016/j.jcis.2009.12.004.

9. Guo Y, Zhao J, Yang S, Yu K, Wang Z and Zhang H, Powder Tech., 2006, 162(2), 83-86.

10. Shamsipur M, Pourmortazavi S, Roushani M, Kohsari I and Hajimirsadeghi S, Microchim Acta, 2011, 173, 445.

11. Ellis M, Ferree D, Funt R and Madden L, Plant Dis., 1998, 82, 428.

12. Xu J and Ji W, J Mater Sci Lett., 1999, 16(2), 115-117; DOI:10.1023/A:1006606316840

13. Khomane R B, Manna A, Mandale A B and Kulkarni B D, Langmuir, 2002, 18(21), 8237-8240; DOI:10.1021/la011567b

14. Kumar A and Jakhmola A, J Colloid Interf Sci., 2006, 297(2), 607-617; DOI:10.1016/j.jcis.2005.11.028

15. Zhu J, Zhu Y, Ma M, Yang L and Gao L, J Phys Chem C, 2007, 111(10), 3920-3926; DOI:10.1021/jp0677851

16. Kienle L, Duppel V and Schlecht S, Soild State Sci., 2004, 6(2), 179-183; DOI:10.1016/j.solidstatesciences.2003.12.002

17. Chin P P, Ding J, Yi J B and Liu B H, J Alloy Compd., 2005, 390(1-2), 255-260; DOI:10.1016/j.jallcom.2004.07.053

18. Jennifer A Dahl, Bettye L S Maddux and James E Hutchison, Chem Rev., 2007, 107(6), 2228-2269; DOI:10.1021/cr050943k

19. Ma Z, Yu J and Dai S, Adv Mater., 2010, 22, 261-285; DOI: 10.1002/adma.200900603

20. Li Z, Luan Y, Mu T and Chen G, Chem Commun., 2009, 14(10), 1258-1260; DOI:10.1039/b819505f

21. Li Z, Luan Y, Wang Q, Zhuang G, Qi Y, Wang Y and Wang C, Chem Commun., 2009, 7(41), 6273-6275; DOI:10.1039/b911508k

22. Meenatchi B and Renuga V, Int J Adv Res., 2014, 2(4), 1107-1116. 